\title{
SUSCEPTIBILITY OF CERTAIN WHEAT VARIETIES TO INFESTATION WITH THE WHEAT SHOOT FLY, ATHERIGONA BEDFORDI EMDEN
}

\author{
LUTFALLAH, ADEL F. ${ }^{1}$, I. I. ISMAIL ${ }^{2}$, \\ M. Y. HASHEM ${ }^{2}$ and SOHEIR F. ABD EL-RAHMAN ${ }^{1}$
}

1. Plant Protection Research Institute, Agric. Res. Center, Dokki. Giza, Egypt.

2. Dept. Economic Entomology\& Pesticides, Fac. of Agric. Cairo Univ., Giza, Egypt

(Manuscript received 11 November 2013)

\begin{abstract}
Wheat, (Triticum aestivum L.), is a major cereal crop in Egypt. Five commercial wheat varieties: Giza 168, Sakha 93, BeniSweif 1 , Gemmeiza 7 and Gemmiza 9 were tested at Giza region for susceptibility to the infestation with Atherigona bedfordi during $2006 / 2007$ and 2007/2008 wheat growing seasons.

In both seasons, Giza 168 was relatively the most susceptible followed by the other varieties. In the $1^{\text {st }}$ season, the infestation means were $19.36,14.91,12.73,10.45$ and $9.36 \%$ on Giza 168, Sakha 93, Gemmeiza 9, Gemmeiza 7 and Beni-Swif 1, respectively. In the $2^{\text {nd }}$ season, the infestation, except Beni-Swif 1 , had a similar trend and the corresponding respective infestation means were $11.17,8.75,7.75,3.58$ and $5.08 \%$.
\end{abstract}

\section{INTRODUCTION}

Most of previous investigations of the wheat insect pests have been largely directed towards the common insects infesting this crop such as aphids, wheat stem sawfly, the lesser grain borer and the rice weevil. Several species of the shoot fly, Atherigona have been found attacking cereal crops such as wheat, sorghum, maize, rice, barley and various millets (sudan and barnyard grass), EL- Serwy. (1998), Salman (2000), Berg et al. (2005), Dhillon et al. (2005), El-Serwy (2006), Salman \& Abdel Moniem (2008), Chikkarugi \& Balikai (2011), Chamarthi et al. (2011).

The shoot fly Atherigona bedfordi is a new recorded pest on the wheat in Egypt causing a damage and yield losses. This study is an attempt clarify certain wheat varieties to the infestation with the wheat shoot fly $A$. bedfordi.

\section{MATERIALS AND METHODS}

This study was carried out in the Agriculture Experimental Station, Faculty of Agriculture, Cairo University at Giza governorate during 2006/2007 and 2007/2008 seasons. The selected wheat varieties were Giza 168, Sakha 93, Beni-Sweif 1, Gemmeiza 7 and Gemmiza 9. The susceptibility of these varieties to the infestation with $A$. bedfordi was investigated during the two seasons. An area of about $1 / 4$ fed. 
was divided into five equal blocks each was also divided into four plots and devoted for one variety. All varieties were sown on Nov. $21^{\text {st }}$ in both seasons and received all regular agricultural practices and chemical control was entirely avoided.

Sampling was started three weeks after planting date and continued weekly until end of the season. Ten tillers, represented the sample, were randomly collected from each plot and examined to record the infested tillers.

Data were analyzed by analysis of variance (ANOVA) and followed by a least significant difference (L.S.D) (SAS Institute Inc., 2003).

\section{RESULTS AND DISCUSSION}

Data in Tables (1\&2) and Fig. (1) revealed that the susceptibility of the tested wheat varieties to the infestation with $A$. bedfordi varied statistically according to the variety. In general, the infestation level was higher during the $1^{\text {st }}$ season than that in the $2^{\text {nd }}$ for all varieties.

In the $1^{\text {st }}$ season, the varity Giza 168 was relatively the most susceptible to the infestation followed by the other respective varieties). The seasonal infestation means were 19.36, 14.91, 12.73, 10.45 and 9.36 for Giza 168, Sakha 93, Gemmeiza 9, Gemmeiza 7 and Beni-Swif 1, respectively, Table (1).

Table 1 . Weekly $A$. bedfordi infestation/40 tillers in the different wheat varieties, 2006-2007 season.

\begin{tabular}{|l|c|c|c|c|c|}
\hline \multirow{2}{*}{$\begin{array}{c}\text { Sampling } \\
\text { dates }\end{array}$} & \multicolumn{5}{|c|}{ Variety } \\
\cline { 2 - 6 } & Giza 168 & Sakha 93 & Gemmeza 9 & Gemmeza 7 & Beni-Swif 1 \\
\hline $11-12-06$ & 7 & 5 & 0 & 4 & 5 \\
\hline $18-12-0$ & 28 & 17 & 16 & 19 & 17 \\
\hline $25-12-0$ & 17 & 17 & 28 & 13 & 19 \\
\hline $01-01-07$ & 21 & 24 & 21 & 15 & 13 \\
\hline $08-01-0$ & 31 & 20 & 21 & 23 & 21 \\
\hline $15-01-0$ & 14 & 10 & 18 & 7 & 6 \\
\hline $22-01-0$ & 22 & 16 & 7 & 5 & 2 \\
\hline $29-01-0$ & 33 & 25 & 15 & 14 & 9 \\
\hline $05-02-0$ & 18 & 12 & 5 & 6 & 2 \\
\hline $12-02-0$ & 15 & 9 & 3 & 6 & 5 \\
\hline $19-02-0$ & 7 & 9 & 6 & 3 & 4 \\
\hline Total & 213 & 164 & 140 & 115 & 103 \\
\hline Mean & $19.36 \mathrm{a}$ & $14.91 \mathrm{~b}$ & $12.73 \mathrm{~b} \mathrm{c}$ & $10.45 \mathrm{c}$ & $9.36 \mathrm{c}$ \\
\hline
\end{tabular}

Means followed by the same letters are insignificantly different from each other

L.S.D. value $=3.71$ 
Table 2. Weekly $A$. bedfordi infestation/40 tillers in the different wheat varieties, 2007-2008 season.

\begin{tabular}{|l|c|c|c|c|c|}
\hline \multirow{2}{*}{$\begin{array}{l}\text { Sampling } \\
\text { dates }\end{array}$} & \multicolumn{5}{|c|}{ Variety } \\
\cline { 2 - 6 } & Giza 168 & Sakha 93 & Gemmeza 9 & Gemmeza 7 & Beni-Swif 1 \\
\hline 15-12-07 & 10 & 0 & 4 & 0 & 0 \\
\hline $22-12-07$ & 11 & 6 & 12 & 2 & 7 \\
\hline $05-01-08$ & 15 & 5 & 9 & 5 & 3 \\
\hline $12-01-08$ & 12 & 7 & 13 & 12 & 10 \\
\hline $19-01-08$ & 6 & 6 & 3 & 5 & 5 \\
\hline $26-01-08$ & 11 & 13 & 10 & 3 & 5 \\
\hline $02-02-08$ & 10 & 10 & 3 & 2 & 11 \\
\hline $09-02-08$ & 12 & 14 & 6 & 1 & 3 \\
\hline $16-02-08$ & 13 & 12 & 11 & 7 & 7 \\
\hline $23-02-08$ & 7 & 10 & 8 & 0 & 4 \\
\hline $02-03-08$ & 8 & 8 & 4 & 3 & 1 \\
\hline Total & 134 & 105 & 93 & 43 & 61 \\
\hline Mean & $11.17 \mathrm{a}$ & $8.75 \mathrm{~b}$ & $7.75 \mathrm{~b}$ & $3.58 \mathrm{c}$ & $5.08 \mathrm{c}$ \\
\hline
\end{tabular}

Means followed by the same letters are insignificantly different from each other L.S.D. value $=2.00$

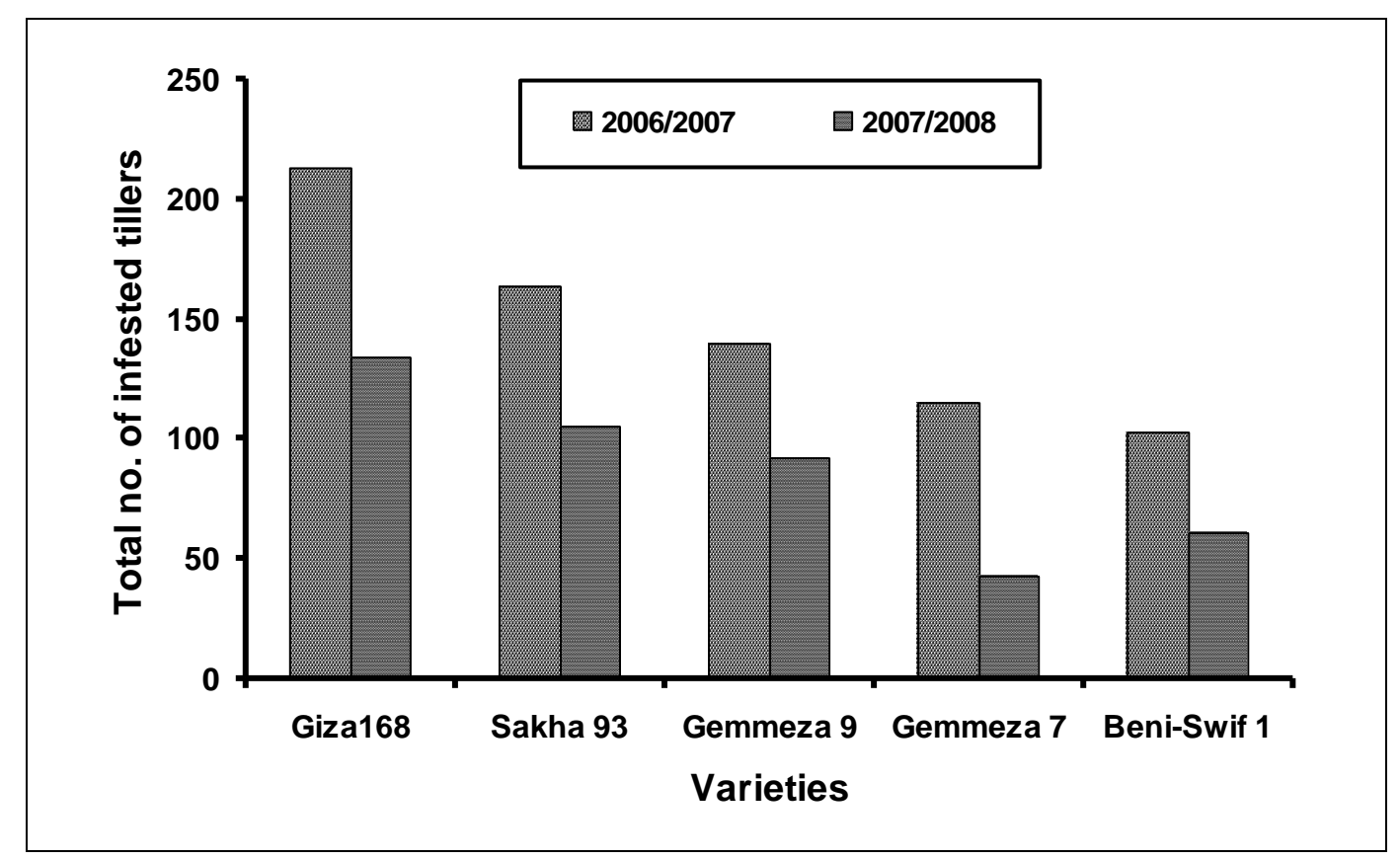

Fig. 1. Infestation of $A$. bedfordi on different wheat varieties in the two successive seasons. 
In the second season, data in Table (2) emphasized that the seasonal infestation means except Beni-Swif 1, had a similar trend, Giza 168 was the most susceptible (11.17) followed by Sakha 93 (8.75), Gemmeiza 9 (7.75), Gemmeiza 7 (3.58) and Beni-Swif 1 (5.08). This may be attributed to the morphological characters of the seedlings as well as to certain other physiological plant mechanisms of the variety and may be the prevailing weather conditions of the season. In both seasons, Giza 168 variety was the highest susceptible to the fly, 19.36 and 11.17 infested tillers, respectively. On the other hand, Beni-Swif 1 variety was the least susceptible to the infestation with 9.36 infested tillers in the $1^{\text {st }}$ season and Gemmeiza 7 variety with 3.58 infested tillers in the $2^{\text {nd }}$ one. This may be due to trichome density and seedling vigour were favourable selection characters for conferring resistance against $A$. bedfordi.

These results are in harmony with those obtained by El-Serwy (1998) who assessed the susceptibility of Sids 4, 6, 7 and 8 varieties for the infestation with Atherigona sp. as dead heart plants. He showed that, Sids 4 was the most susceptible while Sids 7 was relatively the most resistant. Salman (2000) tested also some wheat cultivars for their relative susceptibility to sorghum shoot fly $A$. soccata during 1998/99 and 1999/2000. In both seasons, the highest infestation rates (34.8545.15\%) were observed on Giza 162, Giza 163, Sakha 61, Gemmeza 1 and Sakha 69. Giza 164, Giza 167 and Sids 5 exhibited a medium resistance (22.73-27.77\%). Kamatar and Salimath (2003) stated that the correlation, regression, and path analyses were conducted by screening 650 sorghum germplasm collections for resistance to $A$. soccata. High glossiness of leaf, light green colour leaves, high seedling vigour, taller seedlings, narrow and erect leaves confer resistance to sorghum shoot fly. Shekharappa (2007) evaluated eleven sorghum genotypes for resistance to $A$. soccata. he found that the correlation between the percentage of dead hearts and surface wax content in the susceptible lines was negative and significant. The number of trichomes on the lower leaf surface was negatively associated with the percentage of dead hearts and oviposition preference .Salman and Abdel-Moniem (2008) screened twenty hybrid cultivars of maize for relative susceptibility to shoot fly, $A$. soccata under field conditions at Sohag governorate, Egypt. None of the assessed maize hybrids were found to be resistant but maize hybrids were significantly different in their susceptibility. 


\section{REFERENCES}

1. SAS Institute Inc. 2003. SAS/STAT Version 8.2 (SASinstitute Inc., Cary, NC).

2. Berg, J.V., L. Bronkhorst, M. Mgonja, and A.B. Obilana. 2005. Resistance of sorghum varieties to the shoot fly, Atherigona soccata Rondani (Diptera: Muscidae) in Southern Africa. International Journal of Pest Management. 51(1):15.

3. Chamarthi, S.K., H.C. Sharma, P.M. Vijay and M.L. Narasu. 2011. Leaf surface chemistry of sorghum seedlings influencing expression of resistance to sorghum shoot fly, Atherigona soccata. J. Plant Biochem. Biotechnol. Doi: 10.1007/s13562011-0048-3).

4. Chikkarugi, N.M and R.A. Balikai. 2011. Response of sorghum genotypes in shoot pest nursery to major pests. Res. J. Agric. Sci., 2(1):21-25.

5. Dhillon, M.K., H.C. Sharma, S. Ram and J.S. Naresh. 2005. Mechanisms of resistance to shoot fly, Atherigona soccata in sorghum. Euphytica, 144(3):301312.

6. EL- Serwy, S.A. 1998. A preliminary study on the shoot-fly Atherigona $s p$. (Muscidae) infestation, a new pest of wheat in Egypt. Bull. Ent. Soc. Egypt. 76(21):21-28.

7. EL-Serwy, S.A. 2006. The sorghum shoot fly, Atherigona soccata (Diptera: Muscidae) attacking some gramineous forage crops in Egypt. Egypt. J. Agric. Res., 84(4):1039-1045.

8. Kamatar, M. Y. and P. M. Salimath. 2003. Morphological traits of sorghum associated with resistance to shoot fly, Atherigona soccata Rondani .Indian J. of Plant Prot. 3(1):73-77.

9. Salman, A. M. A. 2000. Screening of certain wheat varieties to the infestation of sorghum shoot fly, Atherigona soccata Rondani, under field conditions in Upper Egypt. Assiut J. Agric. Sci., 31 (5): 1-7.

10. Salman, A.M.A. and A.S.H. Abdel-Moniem .2008. Effect of planting dates and maize hybrids on the infestation with sorghum shoot fly, Atherigona soccata Rondani and its effect on the yield. Archives of Phytopathology and Plant Protection, 41(5): 349-359.

11. Shekharappa 2007. Evaluation of sorghum varieties against shoot fly, Atherigona soccata Rondani. Karnataka J. Agric. Sci., 20(3):651-652. 
مدى قابلية بعض أصناف القمح للأصابة بذبابة البرعم الطرفى

\section{ATHERIGONA BEDFORDI EMDEN (DIPTERA: MUSCIDAE)}

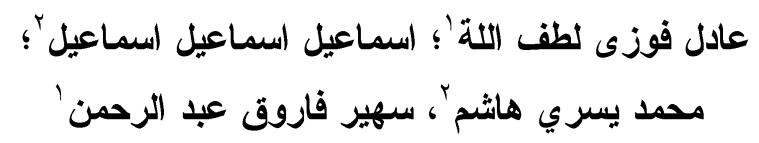

ا ـ معه بحوث وقابة النباتات، مركز البحوث النزراعبة ، دقى ، الجيزة r r كلية الزراعة، جامعة القاهرة ، الجيزة

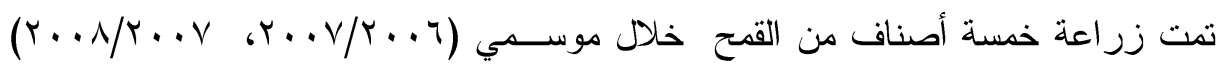

لهذه الدر اسة وهى جيزة ل1 1 1، و سخا با9، و جميزة 9، وجميزة V و بني سويف ا.

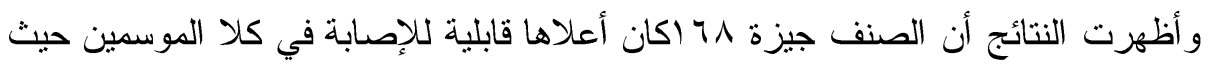

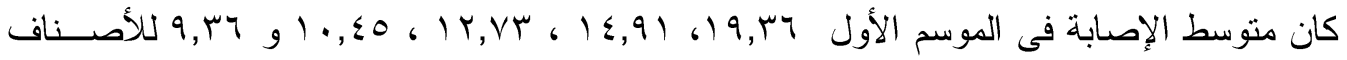

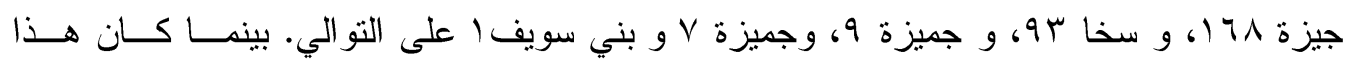

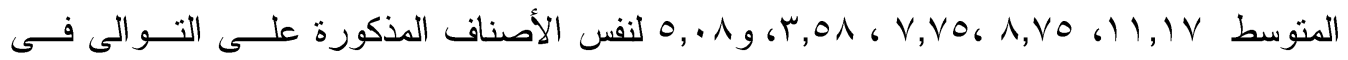

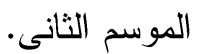

